\title{
Sustainable Shear Behaviour of 2-Span Continuous Reinforced Concrete T-Beams with CFRP Strips
}

\author{
Abdul Aziz Abdul Samad ${ }^{1, *}$, Marwan B.S. Alferjani ${ }^{2}$, Noorwirdawati Ali ${ }^{1}$, Noridah \\ Mohamad $^{2}$, Mohd Hilton Ahmad ${ }^{1}$, Kong Fah Tee ${ }^{3}$, and Priyan Mendis ${ }^{4}$ \\ ${ }^{1}$ Jamilus Research Centre, Universiti Tun Hussein Onn Malaysia, 86400 Parit Raja, Johor, Malaysia \\ ${ }^{2}$ Faculty of Civil and Environmental Engineering, Universiti Tun Hussein Onn Malaysia, 86400 Parit \\ Raja, Johor, Malaysia \\ ${ }^{3}$ Department of Engineering Science, University of Greenwich, Kent ME4 4TB, United Kingdom \\ ${ }^{4}$ Department of Infrastructure Engineering, University of Melbourne, Parkville, 3010 Victoria, \\ Australia
}

\begin{abstract}
Reinforced concrete (RC) structures are generally subjected to various load conditions and are susceptible to environmental impact. With time, most of these structures will be subjected to change in their usage. Unexpected increase in load changes may cause severe damage to the structural components, and eventual leading to various types of structural failure. It is noted that shear failure in nature is a sudden failure and should be avoided at all times. To increase its service life due to shear, structures can be strengthened or repaired using CFRP strips wrapped within the shear span $\left(\mathrm{a}_{\mathrm{v}}\right)$ of the beam. Hence, this paper presents an investigation on the sustainable behaviour of two span continuous RC T-beams strengthened and repaired by wrapping Carbon Fibre Reinforced Polymer (CFRP) strips at intervals along the shear span $\left(a_{v}\right)$ of the beam. The CFRP strips will be orientated in two directions either at $0^{\circ} / 90^{\circ}$ or $45^{\circ} / 35^{\circ}$. Five beams, one control beam, two initially strengthened beams and two precracked and repaired beams were cast and cured in room temperature before testing. All T-beams were designed to fail in shear and are subjected to four-point bending test until failure. Upon completion of the test, all beam specimens shows good sustainable behaviour as the ultimate load and shear load shows an increase in capacity by up to $23 \%$ with improve ductile behaviour.
\end{abstract}

\section{Introduction}

Shear failure of RC beams is mainly caused by the formation of diagonal tension cracks within the web of the beam. This causes the beam to be unstable and consequently causes the structure to fail. In order to resist the shear stresses produced by the applied loads, the shear transfer mechanisms [1] are developed with the beam web as shown in Fig. 1. The

\footnotetext{
*Corresponding author: azizs@uthm.edu.my
} 
figure clearly show the shear force $V$ of RC beam resisted by the combined action of various forces. Hence, the shear force $V$ can be represented by Equation (1) shown below:

$$
V=V_{c c}+V_{d}+V_{c a}
$$

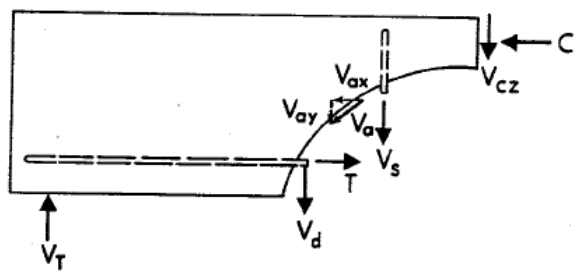

Fig. 1. Shear force transfer mechanism [1]

From Fig. 1, $V_{c c}$ is the un-cracked concrete compression zone, $V_{d}$ is the dowel action of longitudinal reinforcement and $V_{c a}$ is the vertical component of the force due to aggregate interlock or interface shear transfer. Effectively, the shear failure mechanism of RC beams are governed by a number of factors such as the compressive strength of concrete $\left(f_{c u}\right)$, effective depth of the beam $(d)$, maximum aggregate size $\left(d_{a}\right)$, and shear span to depth ratio $\left(a_{v} / d\right)$. It has been reported by Sinha [2] that the behaviour of beams failing in shear can be studied with respect to the different shear span to depth ratio $\left(a_{v} / d\right)$. Three common cases of shear failure (Case I, Case II and Case III) with different $a_{v} / d$ ratio were outlined by Sinha [2] and are as shown in Fig. 2, Fig. 3 and Fig. 4 respectively.

Case I: Shear compression failure, $a_{v} / d=1$ to 2.5

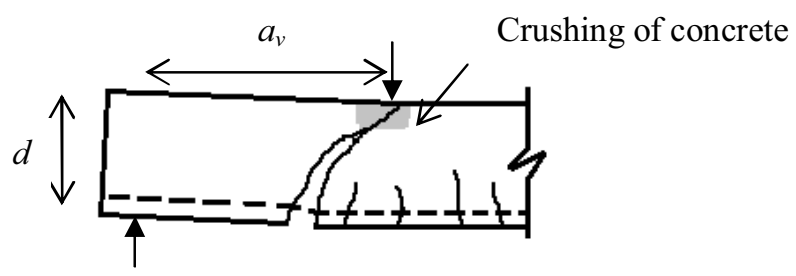

Fig. 2. Shear compression failure [2]

Case II: Shear tension failure, $a_{v} / d=1$ to 2.5

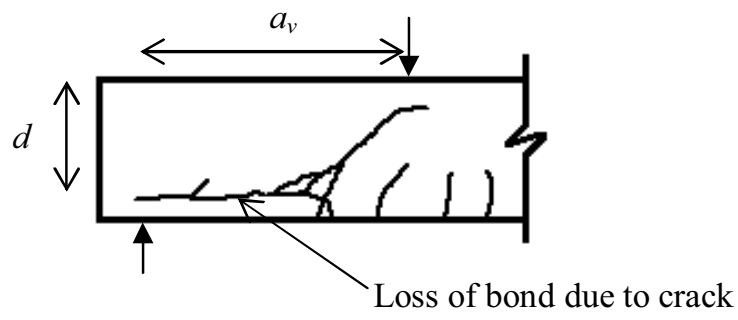

Fig. 3. Shear tension failure [2] 
Case III: Diagonal tension failure, $a_{v} / d \geq 2.5$ to 6

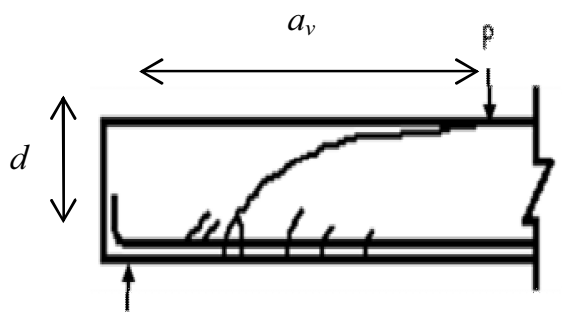

Fig. 4. Diagonal tension failure [2]

To ensure the sustainability and longevity of civil infrastructure, the use of Fibre Reinforced Polymer (FRP) materials for the repair and strengthening of reinforced concrete structures and for other types of construction has become common practice. FRP is a composite material made from strong fibres embedded in a resin matrix, possessing high resistance to corrosion, high strength properties and light weight.

As a material, FRP offers outstanding combination of physical and mechanical properties such as its high tensile strength, it is light weight, it has high stiffness properties, high fatigue strength and has excellent durable properties. Other major characteristics of FRP include its high strength to weight ratio, it has non-conductive, non-corrosive and nonmagnetic properties and is resistant to chemical attack [3,4]. It has also been reported by Alferjani et al. [5], Ali et al. [6] and Shahidan et al. [7] that the application of the FRP composites has been proven to increase the service life contributing to the structures longevity. Another unique property of FRP is that it allows the material to be molded into various shapes and forms, facilitating its flexible use in construction. This permits FRP to be applicable in areas with limited access where traditional techniques would be impractical [8]. However, application of FRP requires the use of additional bonding materials and adhesives, such as epoxy and resins [9], which are relatively expensive compared to traditional materials.

\section{Experimental Work}

The experimental work consists of testing five 2-span continuous RC T-beams with identical size of $150 \mathrm{~mm} \times 320 \mathrm{~mm} \times 3650 \mathrm{~mm}$, flange width of $400 \mathrm{~mm}$ and flange thickness of $120 \mathrm{~mm}$. All T-beams had identical reinforcement detailing, including nominal stirrups and longitudinal reinforcement. Fig. 5 shows the beam size and reinforcement details. All beams were designed to fail in shear and were strengthened and repaired using Carbon Fibre Reinforced Polymer (CFRP) strips from SikaWrap-160 BI C/15 [10], see Fig. 6. The CFRP strips were orientated at, either, $0^{\circ} / 90^{\circ}$ (Fig. 7(a)) and $45^{\circ} / 135^{\circ}$ (Fig. 7(b)). Due to the limitations of the test frame, the specimens were subjected to a shear span to effective depth ratio $\left(a_{v} / d\right)$ of 1.85 . The five beam specimens includes one control beam and four reinforced concrete T-beam. All the specimens are labelled as follows: Control Beam (T1.85-C), Beam 1 (T1.85-U-V1), Beam 2 (T1.85-U-V2), Beam 4 (T1.85-U-S) and Beam 4 (T1.85-L-S). Beam 1 and Beam 2 are initially strengthened beams whilst Beam 3 and Beam 4 are precracked and repaired beams. Observed that Beam 1, Beam 3 and Beam 4 were wrapped with a single layer of CFRP strip whilst Beam 2 with two layers. The investigation comprises of its ultimate load and shear capacity, load-deflection profile, its modes of failure and crack pattern of the specimens. All specimens had similar targeted concrete compressive strength of $30 \mathrm{~N} / \mathrm{mm}^{2}$, main reinforcement tensile strength of 460 
$\mathrm{N} / \mathrm{mm}^{2}$ and stirrups tensile strength of $250 \mathrm{~N} / \mathrm{mm}^{2}$. The selected fiber reinforced polymer was a bi-directional CFRP sheet cut at strips of $80 \mathrm{~mm}$ in width and were spaced at $150 \mathrm{~mm}$ centre to centre (see Fig. 7(a) and 7(b)). Table 1 shows the material properties and its strength for concrete, steel and CFRP. The application of the CFRP strips was conducted by placing a coat of Sikadur-330 epoxy [9] to the concrete surface, see Fig. 8. The CFRP strips were then placed accordingly within the shear span $\left(a_{v}\right)$ and allowed to cure for one week before being placed in the testing frame. Note that Beam 3 and Beam 4 (as precracked and repaired beams) were preloaded up to $70 \%$ of the ultimate load to create the initial shear cracks of the beams. Upon reaching the $70 \%$ load, the beams were unloaded followed by the application of the CFRP strips along the initial shear cracks.

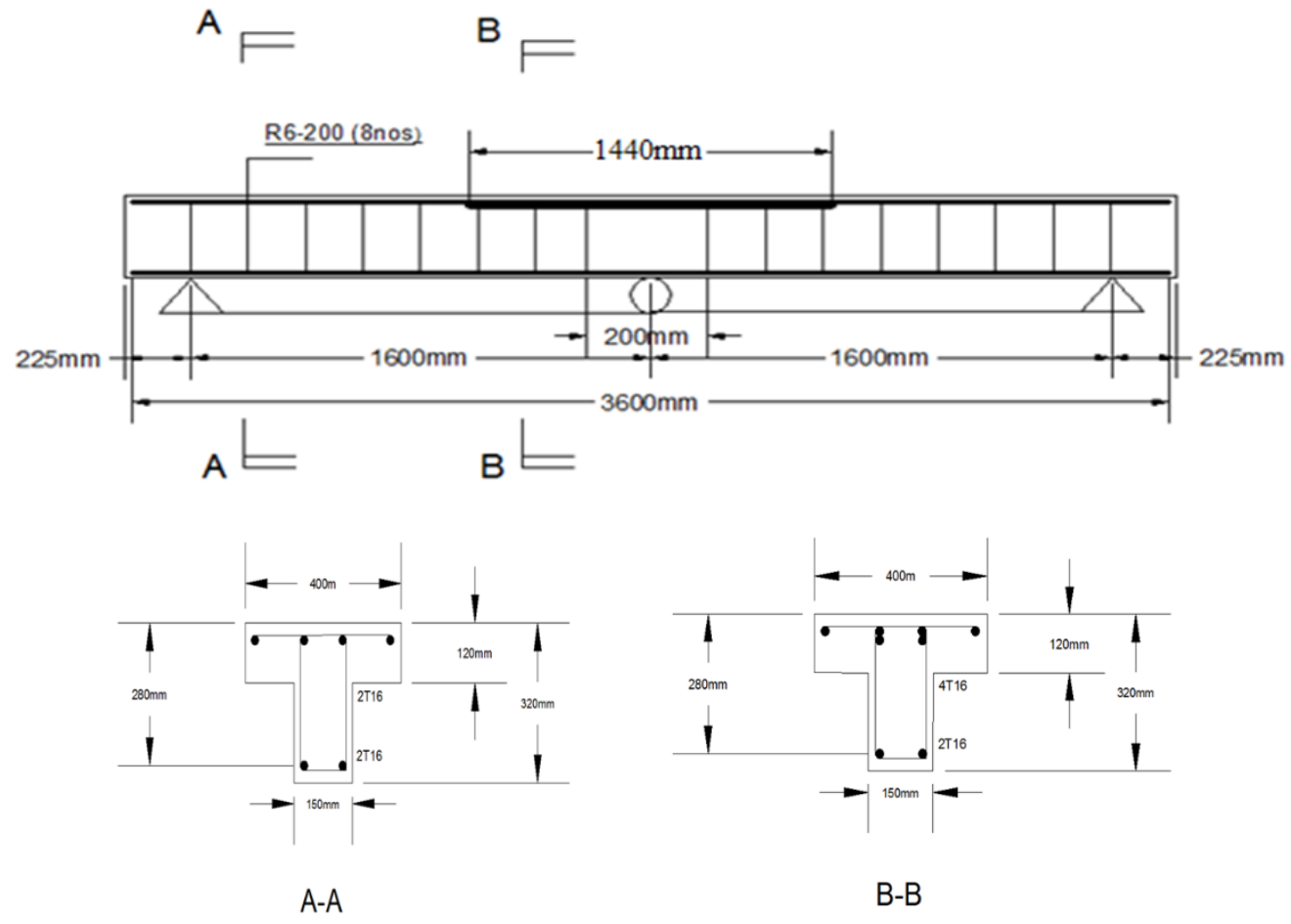

Fig. 5. Reinforcement and cross section details

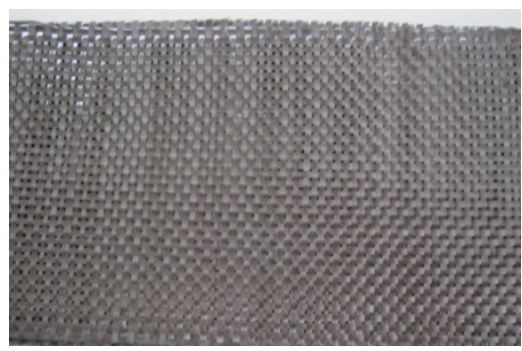

Fig. 6. SikaWrap-160 BI C/15 
Table 1. Material and strength properties for concrete, steel and CFRP

\begin{tabular}{|c|c|c|c|c|}
\hline Concrete & & days & \multicolumn{2}{|c|}{28 days } \\
\hline $\begin{array}{l}\text { Compression } \\
\text { Strength, } \\
f_{c u}(M P a)\end{array}$ & \multicolumn{2}{|c|}{26} & \multicolumn{2}{|c|}{30} \\
\hline Steel & \multicolumn{2}{|c|}{$16 \mathrm{~mm}$ diameter } & \multicolumn{2}{|c|}{$6 \mathrm{~mm}$ diameter } \\
\hline $\begin{array}{c}\text { Yield Strength, } \\
f y(M P a)\end{array}$ & \multicolumn{2}{|c|}{530} & \multicolumn{2}{|c|}{272} \\
\hline \multirow{2}{*}{ CFRP } & $\begin{array}{l}\text { Fibre } \\
\text { Orientation }\end{array}$ & $\begin{array}{l}\text { Fabric Thickness } \\
\qquad(\mathrm{mm})\end{array}$ & $\begin{array}{l}\text { Tensile Strength } \\
(M P a)\end{array}$ & $\begin{array}{l}\text { Tensile Modulus } \\
\qquad(M P a)\end{array}$ \\
\hline & $0^{\circ} / 90^{\circ}$ & $0.0046 /$ direction & 3,800 & 230,000 \\
\hline
\end{tabular}

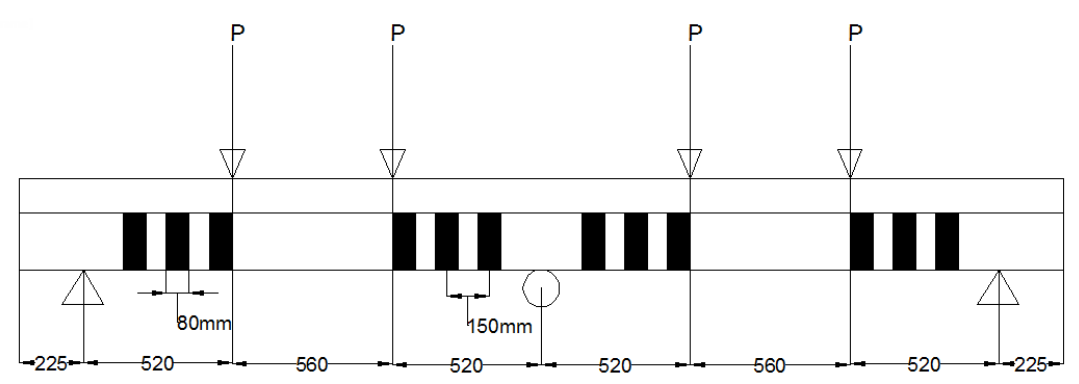

(a) CFRP orientation at $0^{\circ} / 90^{\circ}$

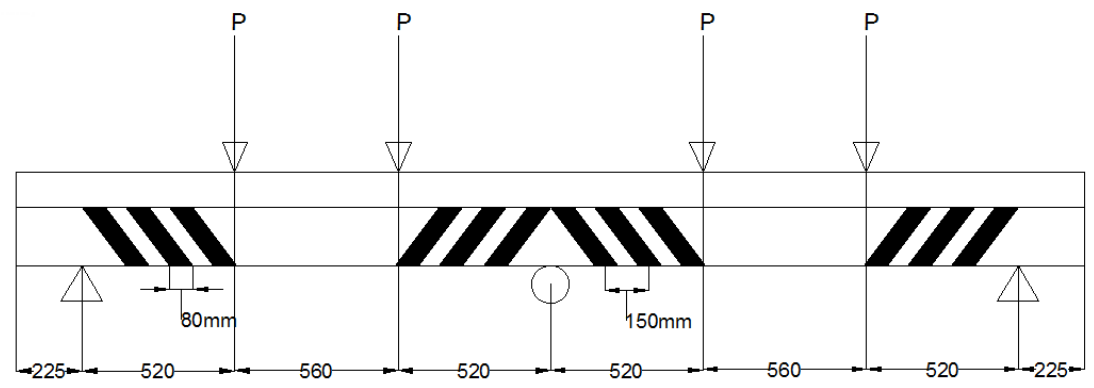

(b) CFRP orientation at $45^{\circ} / 135^{\circ}$

Fig. 7. CFRP orientation of 2 span continuous RC T-beams

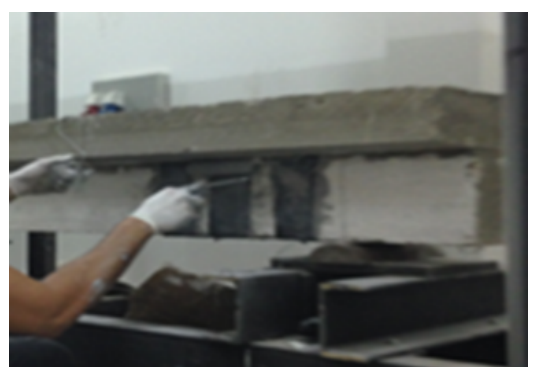

Fig. 8. Application of CFRP at shear span $\left(a_{v}\right)$ 


\section{Results and discussions}

\subsection{Ultimate load and shear load}

Generally at failure, all T-beams either initially strengthened (Beam 1 and Beam 2) or precracked and repaired (Beam 3 and Beam 4) showed higher ultimate load values compared to control beam (T1.85-C). This is clearly indicated in Table 2 where Beam 1, Beam 2, Beam 3 and Beam 4 achieved an ultimate load of $241.2 \mathrm{kN}$ up to $247.7 \mathrm{kN}$ which compared to $220.4 \mathrm{kN}$ for the control beam. This is an increase of approximately $10 \%$ to $12 \%$. Likewise, the shear capacity of the beam also showed good enhancement values. By comparison with control beam T1.85-C, Beam 1 and Beam 2 showed shear enhancement of $9.1 \%$ and $17.0 \%$ respectively whilst Beam 3 and Beam 4 showed enhancement of $6.9 \%$ and $13.2 \%$. The higher ultimate load and shear capacity clearly indicates that by externally bonding CFRP strips within the shear span of the T-beams (either initially strengthened or precracked and repaired) ensures its compositeness and its ability to carry more loads.

Table 2. Experimental results $\left(a_{v} / d=1.85\right)$

\begin{tabular}{|c|c|c|c|c|c|}
\hline $\begin{array}{c}\text { Beam } \\
\text { Specimens }\end{array}$ & $\begin{array}{c}\text { CFRP } \\
\text { Orientation }\end{array}$ & $\begin{array}{c}\text { Ultimate } \\
\text { Load } \\
(k N)\end{array}$ & $\begin{array}{c}\text { Shear Force } \\
(k N)\end{array}$ & $\begin{array}{c}\text { Shear } \\
\text { Enhancement } \\
(k N)\end{array}$ & $\begin{array}{c}\% \\
\text { Shear } \\
\text { Enhancement }\end{array}$ \\
\hline $\begin{array}{c}\text { Control } \\
\text { 11.85-C }\end{array}$ & $0^{\circ} / 90^{\circ}$ & 220.4 & 73.3 & 0 & 0 \\
\hline $\begin{array}{c}\text { Beam 1 } \\
\text { T1.85-U-V1 }\end{array}$ & $0^{\circ} / 90^{\circ}$ & 247.7 & 82.4 & 9.1 & 12.4 \\
\hline $\begin{array}{c}\text { Beam 2 } \\
\text { T1.85-U-V2 }\end{array}$ & $0^{\circ} / 90^{\circ}$ & 271.6 & 90.3 & 17.0 & 23.3 \\
\hline $\begin{array}{c}\text { Beam 3 } \\
\text { T1.85-U-S }\end{array}$ & $0^{\circ} / 90^{\circ}$ & 241.2 & 80.2 & 6.9 & 9.5 \\
\hline $\begin{array}{c}\text { Beam 4 } \\
\text { T1.85-L-S }\end{array}$ & $45^{\circ} / 135^{\circ}$ & 260.1 & 86.5 & 13.2 & 18.0 \\
\hline
\end{tabular}

Note: $\mathrm{T}=\mathrm{T}$-beam; $1.85=$ shear span to depth ratio; $\mathrm{U}=\mathrm{CFRP}$ strips at $0^{\circ} / 90^{\circ}$ orientation;

$\mathrm{L}=\mathrm{CFRP}$ strips at $45^{\circ} / 135^{\circ}$ orientation; $\mathrm{V} 1=$ initially strengthened, single layer; $\mathrm{V} 2$ = initially strengthened, two layers; $\mathrm{S}=$ precracked and repaired; $\mathrm{C}=$ control beam

\subsection{Load-deflection profile}

The load-deflection profiles are shown in Fig. 9(a) for Beam 1, Beam 2 (initially strengthened) and Fig. 9(b) for Beam 3, Beam 4 (precracked and repaired beams). Comparison with deflection profile of the control beam (T1.85-C) and findings from Jayaprakash et al. [11, 12] was made for further clarity. By observation, the deflection profile for initially strengthened beams (Beam 1 and Beam 2) showed stiffer responses compared to Jayapakash et al. [11, 12]. However, less displacement values were recorded at failure but still shows an improved ductility behavior compared to control beam. Results show that displacement values for Beam 1 and Beam 2 was recorded at $12 \mathrm{~mm}$ and $14 \mathrm{~mm}$ respectively.

For Beam 3 and Beam 4 (precracked and repaired), similar trends and close proximity of deflection profile was observed with Jayaprakash et al. [11, 12]. By comparison with the control beam, the deflection at failure was slightly higher at $11 \mathrm{~mm}$ and $13 \mathrm{~mm}$ for Beam 3 and Beam 4 respectively indicating an improve ductile behaviour. 


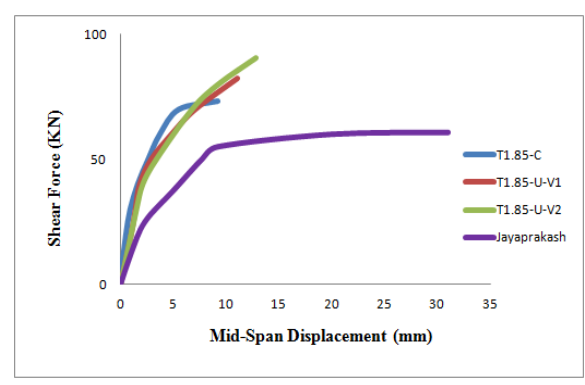

(a) Initially strengthened

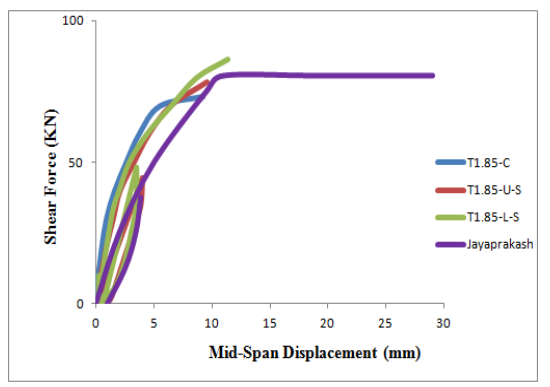

(b) Precracked and repaired

Fig. 9. Load-deflection profile

\subsection{Mode of failure and crack pattern}

The mode of failure and crack patterns for Control Beam, Beam 1 to Beam 4 is shown in Fig. 10(a) to (e). For control beam (T1.85-C) diagonal shear cracks developed as load was increased until total failure in shear occurs. Similar crck patterns were also observed For Beam 1 to Beam 4. However, upon failure, all strengthened or repaired beams failed by simultaneously rupturing the CFRP strips along its major diagonal shear crack of the beam.

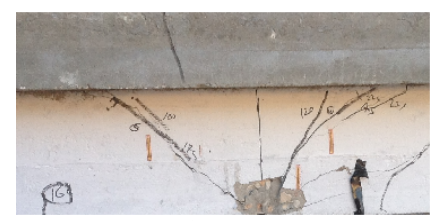

(a) Control Beam (T1.85-C)

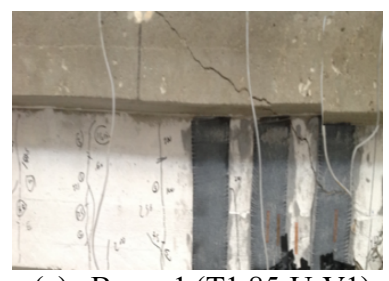

(a) Beam 1 (T1.85-U-V1)

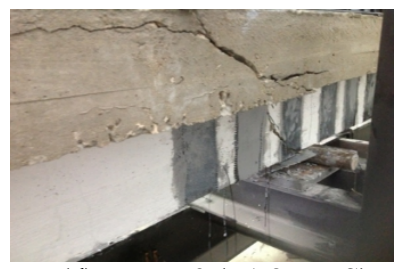

(d) Beam 3 (T1.85-U-S)

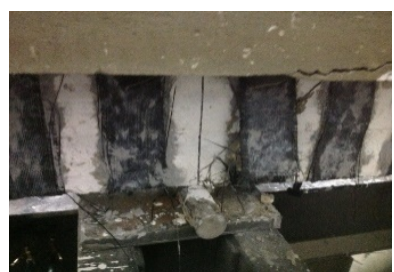

(c) Beam 2 (T1.85-U-V2)

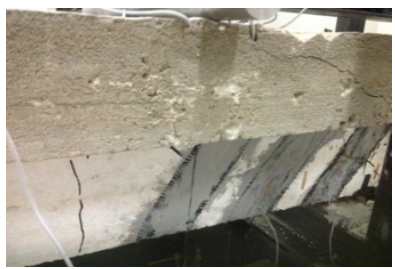

(e) Beam 4 (T1.85-L-S)

Fig. 10. Crack patterns and modes of failure 


\section{Conclusions}

The sustainable behaviour of five full scale 2-span continuous RC T-beams with shear deficiencies were investigated. All beams were tested under a four-point bending test with shear span to effective depth ratio $\left(a_{v} / d\right)$ of 1.85 . The T-beams were either initially strengthened or precracked and repaired by wrapping CFRP strips at intervals along the shear span $\left(a_{v}\right)$. Results indicated that the strengthened and repaired T-beams shows good composite responses with increase in ultimate load and shear load of up to $23 \%$. The strengthened and repaired T-beams also shows improve ductility behavior with higher displacement values then the control beam.

The authors acknowledge the funding received from the Fundamental Research Grant Scheme (FRGS) Vot. No. 1573 from the Ministry of Higher Education of Malaysia and the support received from Jamilus Research Centre, Universiti Tun Hussein Malaysia.

\section{References}

[1] J.K. Wight and J.G. MacGregor, Reinforced concrete: Mechanics and design, 6th ed. Pearson, Upper Saddle River, New Jersey (2012)

[2] S.N. Sinha, Reinforced concrete design, 2nd ed. Tata McGraw-Hill (2002)

[3] A. Khalifa and A. Nanni, Improving shear capacity of existing RC T-section beams using CFRP composites, Cement and Concrete Composites, 22(2), 165-174 (2000)

[4] A. Khalifa and A. Nanni, Rehabilitation of rectangular simply supported RC beams with shear deficiencies using CFRP composites, Construction and Building Materials, 16, 135-146 (2002)

[5] M.B.S. Alferjani, A.A. Abdul Samad, B.S. Elrawaff and N. Mohamad, Experimental and theoretical investigation shear strengthening of RC precraced continuous T-beams using CFRP strips, Int. J. of Engineering, Transactions B: Applications, 28(5), 671-676 (2015)

[6] N. Ali, A.A. Abdul Samad, N. Mohamad and J. Jayaprakash, Shear behaviour of precracked continuous beams repaired using externally bonded CFRP strips, Procedia Eng., 53, 129-144 (2013)

[7] S. Shahidan, S. Salwa, M. Zuki, C. K. Keong and J. Jayaprakash, Repaired of firedamaged concrete-filled double skin steel tubular (CFDST) columns with fiber reinforced polymer (FRP), ARPN J. Engineering of Applied. Sciences, 11(6), 37183725 (2016)

[8] M.B.S. Alferjani, A.A. Abdul Samad, B.S. Elrawaff, O. Elzaroug and N. Mohamad, Study on shear strengthening of RC continuous T-beams using different layers of CFRP strips, AIP Conference Proceedings, 1660, 070107 (2015)

[9] Sika Manufacturer's Product Data Sheet, Switzerland, (Supplier: Sika Kimia Sdn. Bhd.), Sika Wrap®-330. 2-party epoxy impregnation resin. Edition 0209/1

[10] Sika Manufacturer's Product Data Sheet, Switzerland, (Supplier: Sika Kimia Sdn. Bhd), Sika Wrap ${ }^{\circledR}-160$ BI-C/15. Woven carbon fiber fabric for structural strengthening. Edition 11/09/2007

[11]J. Jayaprakash, A.A. Abdul Samad, A. Anvar Abbasovich and A.A. Abang Ali, Shear capacity of precracked and non-precracked reinforced concrete shear beams with externally bonded bi-directional CFRP strips, Construction and Building Materials, 22(6), 1148-1165 (2008)

[12]J. Jayaprakash, A.A. Abdul Samad, A.A. Ashrabov and K.K. Choong, Experimental investigation on shear resistance behaviour of RC precracked and non-precracked $\mathrm{T}$ beams using discrete CFRP strips, Int. J. of Integrated Engineering, 1(2), 1-15 (2009) 